THE EFFECT OF FINANCIAL DEVELOPMENT ON THE INVESTMENT-CASH FLOW RELATIONSHIP

\title{
CROSS-COUNTRY EVIDENCE
} FROM EUROPE

by Bo Becker and Jagadeesh Sivadasan 


\section{WORKING PAPER SERIES} NO 689 / OCTOBER 2006 ECB LAMFALUSSY FELLOWSHIP PROGRAMME

\section{THE EFFECT OF FINANCIAL DEVELOPMENT ON THE INVESTMENT-CASH FLOW RELATIONSHIP}

\section{CROSS-COUNTRY EVIDENCE FROM EUROPE'}
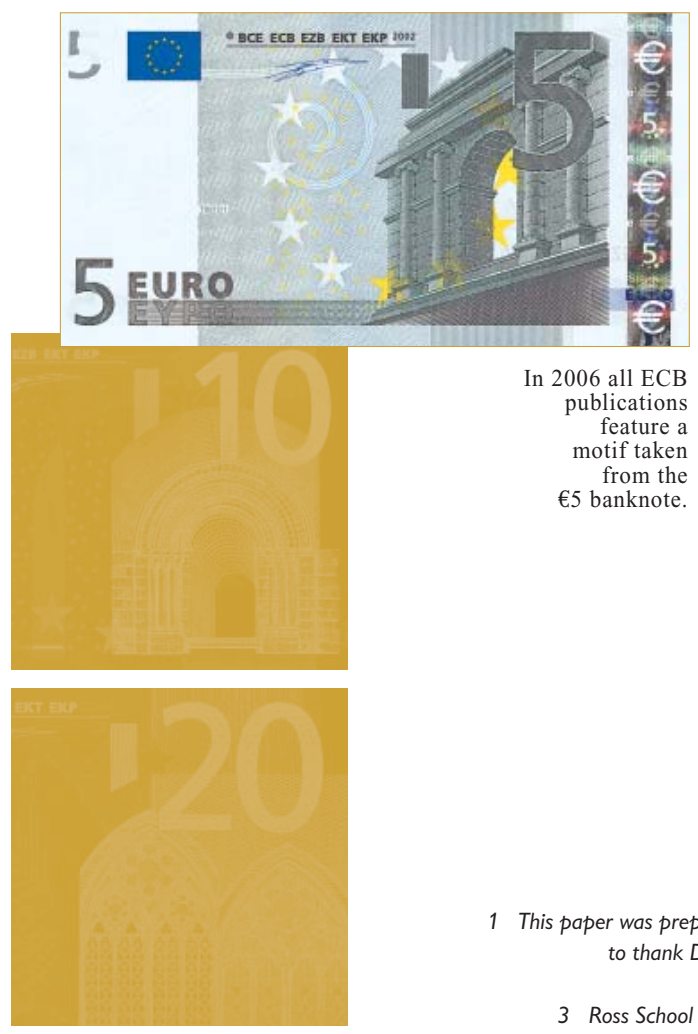

by Bo Becker ${ }^{2}$ and Jagadeesh Sivadasan ${ }^{3}$

This paper can be downloaded without charge from http://www.ecb.int or from the Social Science Research Network electronic library at http://ssrn.com/abstract_id $=936949$ 


\section{Lamfalussy Fellowships}

This paper has been produced under the ECB Lamfalussy Fellowship programme. This programme was launched in 2003 in the context of the ECB-CFS Research Network on "Capital Markets and Financial Integration in Europe". It aims at stimulating high-quality research on the structure, integration and performance of the European financial system.

The Fellowship programme is named after Baron Alexandre Lamfalussy, the first President of the European Monetary Institute. Mr Lamfalussy is one of the leading central bankers of his time and one of the main supporters of a single capital market within the European Union.

Each year the programme sponsors five young scholars conducting a research project in the priority areas of the Network. The Lamfalussy Fellows and their projects are chosen by a selection committee composed of Eurosystem experts and academic scholars. Further information about the Network can be found at http://www.eu-financial-system.org and about the Fellowship programme under the menu point "fellowships".

\footnotetext{
(C) European Central Bank, 2006

Address

Kaiserstrasse 29

60311 Frankfurt am Main, Germany

Postal address

Postfach 160319

60066 Frankfurt am Main, Germany

Telephone

+496913440

Internet

http://www.ecb.int

Fax

+496913446000

Telex

$411144 \mathrm{ecb} d$

All rights reserved

Any reproduction, publication and reprint in the form of a different publication, whether printed or produced electronically, in whole or in part, is permitted only with the explicit written authorisation of the ECB or the author(s).

The views expressed in this paper do not necessarily reflect those of the European Central Bank.

The statement of purpose for the ECB Working Paper Series is available from the ECB website, http://www.ecb.int. 


\section{CONTENTS}

Abstract

Non-technical summary

1 Introduction

2 Background and literature

2.1 Cash flow sensitivity of investment

2.2 Firm size distributions, entry and exit

2.3 Allocations

2.4 Aggregate frictions

3 Predictions

4 Data

4.1 Amadeus

4.2 Other data sources

4.3 Sample overview

5 Results

6 Extensions and robustness 18

6.1 Conglomerates

6.2 Excluding financial and real estate firms

6.3 Western versus Eastern Europe 19

6.4 Asset liquidity 20

7 Conclusions 2I

References 22

Tables and figures 25

European Central Bank Working Paper Series 40 


\begin{abstract}
We investigate financing constraints in a large cross-country data set covering most of the European economy. Firm level investment sensitivity to cash flow is used to identify financing constraints. We find that the sensitivities are significantly positive on average, controlling for country and industry fixed effects, as well as firm level controls. Most importantly, the cash flow sensitivity of investment is lower in countries with better-developed financial markets. This suggests that financial development may mitigate financial constraints. This effect is weaker in conglomerate subsidiaries, which are likely to have access to internal capital markets and depend less on the outside financial environment, and possibly for firms in industries with highly liquid assets as well. This result sheds light on the link between financial and economic development.
\end{abstract}

JEL Codes: E22, E44, G31, L10.

Key words: Financial Constraints, Investment, Europe, Financial Development 


\section{Non-technical summary}

A large research literature has established that firms tend to invest more when they have more internal resources available. This has been interpreted as a sin that external finance is not available for all firms at all times (at least not on attractive terms). Firms whose investment is limited because of a lack of internal resources and a lack of access to external financing are referred to as "financially constrained". Our research compares financial constraints across European countries. We examine companies of various sizes in a large cross-country data set covering most of the European economy. As is standard in the literature, we identify financial constraints with investment to cash flow sensitivity at the firm level, i.e. we take firms in a country to be more financially constrained if their investment responds more to internal cash flow (than that in other countries). In line with the previous literature, we find that the sensitivities are significantly positive on average, meaning that firms invest more when internal resources are plentiful. This holds when we control for country and industry effects, as well as firm characteristics.

Most importantly, the cash flow sensitivity of investment is lower in countries with better-developed financial markets. Countries such as Switzerland and the Netherlands (which rank high on both our measures of financial development) exhibit a lower impact of firm cash flow on investment, on average, than countries such as Hungary, Finland and Italy (which rank relatively low). This suggests that financial development reduces the impact of financial constraints, presumably by allowing easier access to external finance for those firms that need it.

Conglomerate subsidiaries have access to internal capital markets (i.e. transfers from the parent company) and therefore depend less on outside finance. It is therefore predicted that they should face lower financial constraints, and, consequently, benefit less from financial development, than free-standing firms. Indeed, we find that the effect of financial development is weaker in conglomerate subsidiaries. This supports the theory that financial development reduces constraints to outside financing. Our results shed light on the link between financial and economic development, and provides a mechanism for how financial development may help economic growth. 


\section{Introduction}

Recent research has emphasized that firm heterogeneity in productivity is substantial, even within narrow sectors, and that productivity variation within industries is important relative to cross-industry differences. Firm- and plant-level evidence shows that the reallocation of capital from less productive to more productive establishments plays a significant role in accounting for aggregate productivity growth. ${ }^{1}$ The research has proved that resource allocation across firms is an important determinant of aggregate (or average) productivity and reallocation is an important driver of productivity growth. There are ample reasons to suspect that the allocation and reallocation of resources across firms is affected by input market contracting. For example, Bertrand, Schoar and Thesmar (2004) show that bank deregulation in France changed the allocation of credit toward profitable firms and firms with good investment opportunities.

This study compares investment constraints across European countries, allowing us to identify some institutional factors that affect investment constraints. We use a firm-level data set across 38 European countries (of which 21 have the required country-level data and are used in regressions). We adopt the broad methodology originally suggested by Fazzari, Hubbard and Petersen (1988), who proposed that positive coefficient on cash flows to assets in a regression of investment on cash flow and market to book value $(\mathrm{Q})$ suggested presence of financial constraints. ${ }^{2}$ Because we focus on a large number of firms without stock prices (since these are unlisted) and hence without data on $Q$, we attempt to control for investment opportunities with alternative controls. We use two alternative sets of controls, one based on an Euler equation and one based on introducing a dynamic error structure to a static capital demand equation. These specifications are drawn from the literature examining the investment

${ }^{1}$ See Bartelsman and Doms (2000) for a survey of research on firm-level productivity differences. See e.g. Davis and Haltiwanger (1996) about productivity growth and Foster, Haltiwanger and Krizan (1998) for an overview and evidence on both growth and levels. See Roberts and Tybout (1996) for nonUS evidence.

${ }^{2}$ All our results should be interpreted keeping in mind important critiques of using cash flow sensitivity of investments as a proxy for financial constraints. These critiques are discussed in more detail in Section 1.1. 
behavior of unlisted firms (and are especially close to the specifications in Bond, Elston, Mairesse and Mulkay (2003)).

We find that in our dataset there is a strongly positive coefficient on the cash flow, suggesting the presence of financial constraints. We also find that the cash flow sensitivity of investment is lower in countries with better finance, which suggests that investment is less likely to be constrained in countries with better financial development. In other words, better input markets reduce the dependence of firms on internal resources. This finding is consistent with Demirgüç-Kunt and Maksimovic (1998) who show that fewer firms are constrained in countries with better financial systems. Our results extend the Bond et al (2003) study to larger sample of countries, and our results suggest a somewhat different effect of financial development on firm-level investment behavior. ${ }^{3}$

We undertake a number of additional robustness checks and extensions of our basic results. First, we examine the cash-flow sensitivity and the role of financial development on the investment behavior of conglomerate firms. We find that conglomerate firms, which have access to internal capital markets, show lower cash flow sensitivities of investment. Further, we find that better financial markets have weaker influence on financial constraints for conglomerate firms. This is what could be expected if conglomerates indeed ameliorate cash flow constraint at their subsidiary firms through reallocation of capital through an internal capital market (though there may still be constraints on group level investment).

Second, we examine if our results are driven by the presence of firms in the financial services and real estate sectors, where measured investment behavior could be driven by a number of factors specific to the industry. These firms comprise only a small fraction of our total sample and we find our results robust to the exclusion of these firms.

Third, we check if our results are driven simply by broad differences in investment behavior for Eastern European firms, by examining the basic regressions separately for Western

${ }^{3}$ Bond et al (2003) cautiously interpret their findings of a higher coefficient on cash flows for the United Kingdom as suggesting that "the market oriented financial system in the United Kingdom performs less well in channeling investment funds to firms with profitable investment opportunities than do the continental European financial system". They caution that their results could be subject to other interpretations. Our findings suggest that a better developed banking and bond market may in fact help to reduce the dependence of firms on internal finances for undertaking investments. 
and Eastern European firms. The identification of the effects we are interested in is weakened by the reduction of sample sizes, especially for Eastern Europe - we are left with only seven countries in Eastern Europe. Our findings provide no evidence for differences in the importance of financial development between East and West. ${ }^{4}$

Fourthly, we examine investment behavior of firms in industries with highly liquid assets vs. industries with less liquid assets. The expected effects are somewhat ambiguous. On the one hand, firms with liquid assets are more likely to be able to use their assets as collateral for external financing. Their financial constraints are therefore perhaps less related to financial development and financial sophistication. On the other hand, Myers and Rajan (1998) suggest that banks may be more reluctant to lend to firms with highly liquid assets as they may fear that managers could more easily manipulate assets in these industries. To test these ideas, we use a liquidity ranking of industries based on US data on asset trades by industry, which we assume is applicable to the same industries in Europe. Our results suggest, tentatively, that firms in industries with less liquid assets may benefit more from financial development.

The rest of the paper is organized as follows: Section 1 presents related research, section 2 discusses our theoretical predictions, Section 3 discusses data sources the sample and Section 4 presents the baseline results. In Section 5 we examine extensions of the baseline specifications and conduct some robustness checks. Section 6 concludes.

\section{Background and literature}

The closest paper to this is Demirgüç-Kunt and Maksimovic (1998) who find that countries with better financial development see relatively more firms growing faster than predicted by internal accounting data. There are several differences. We use firm level data in our main regressions, rather than country averages. This difference in methodology means that we exploit more variation in the data, at the cost of some added complexity. We also make different assumptions on firm growth and investment in order to identify the effect of external finance. Most importantly, we study the effect of internal cash flow on investment, rather than the fraction of firms growing faster than predicted. In that sense, we extend Demirgüç-Kunt and

${ }^{4}$ We also undertook a country-by country analysis of investment, and results here confirmed our findings (see Appendix). 
Maksimovic's results: better financial development not only helps some firms grow faster, it also particularly helps firms which are likely to be financially constrained.

\subsection{Cash flow sensitivity of investment}

We use the sensitivity of investment to cash flow as a measure of the frictions involved in the allocation of resources to firms as first suggested by Fazzari, Hubbard and Petersen (1988). They argued that if external financing is available without frictions and at zero cost, a firm's investment should be determined only by its investment opportunities, not by its internal resources. Empirically, Fazzari et al argue that $Q$ (market value of equity over book value) captures investment opportunities and that cash flow captures internal resources. They find that cash flow often predicts investment, but that $Q$ often does not. Importantly, non-dividend paying firms in the US (Fazzari et al) and firms in Japan not affiliated with a Keiretsu business group (Hoshi, Kashyap Scharfstein 1991) exhibit higher correlations between cash flows and investment than other firms. This is consistent with these firms being more constrained than others. ${ }^{5}$

A large literature has followed these early findings (see e.g. Bond and van Reenen (2006) for a recent survey), attempting to use cash-flow sensitivity as a sign of financial frictions. However, concerns have been raised about the validity of the methodology. In an influential paper, Kaplan and Zingales (1997) make two points. First, they argue that the theoretical predictions are more ambiguous than Fazzari et al suggest. Second, they argue that empirically, dividend payers are not necessarily less constrained than other firms. These critiques have been expanded and developed. For example, Alti (2003) shows that young firms will naturally have less informative $Q$ than more mature firms (because of their skewed future payoffs). Young firms' investment may be correlated with cash flow not because they are constrained but because their cash flow contains information about short term investment opportunities beyond Q. Abel and Eberly (2002) make a related point: small, fast-growing firms may exhibit cash flow sensitivity because their $Q$ does not quite capture investment opportunities, even if their financing is frictionless. Gomes (2001) also suggest that $Q$ will not properly capture underlying shocks. All these papers imply that non-zero coefficients cannot necessarily be interpreted as

\footnotetext{
${ }^{5}$ See e.g. Campello (2004) for more recent evidence from US banks.
} 
evidence of constraints. Note, however, that Gomes does find consistently higher cash flow coefficients when constraints are higher (table 5, 9, 15). ${ }^{6}$

Given these important critiques, we will not focus on the existence of positive cash flow coefficients per se, but instead test whether they systematically vary with levels of financial development. We are essentially testing if some countries have higher sensitivity of investment to cash flow because their markets for external capital provision are less well developed. We do not compare firms, as much of the previous literature does, but countries. Interpreting higher cash flow sensitivities in a country as a negative effect of worse financial development is less ambiguous.

Perhaps the most closely related paper in this group is Bond et al. (2003) which studies the role of cash flow in investment equations for European firms from four countries. Like us, they study the differences in cash flow coefficients across countries. We extend their methodology of comparing countries, but because we have a larger sample with more countries, we can do this more rigorously, i.e. we test formally whether cash flow coefficients are related to measures of financial development. ${ }^{7}$

\subsection{Firm size distributions, entry and exit}

Our paper is related to evidence on how growth, entry and exit depends on frictions and institutions in Europe. Using a similar data set, Klapper, Laeven and Rajan (2003) show that financial development and labor regulation as well as entry regulation affect entry rates across

6 See also Moyen (2004), who shows that financing constraints may generate data similar to Fazzari et al's and later findings.

7 The Bond et al paper also undertakes a careful GMM based estimation of the regression specifications. Our investigations of different GMM specifications yielded highly imprecise and noisy results across specifications -- the GMM approach appears to demand too much of our data. (Also given our large data sizes, GMM estimations are extremely resource and time intensive, even when run separately country-by-country). Since we focus on differences in cash flow/profitability coefficients across countries, we expect any endogeneity issues biasing coefficients up or down to not be a severe issue insofar as the amount of bias is uncorrelated with financial development. This expectation is supported by results in Bond, et al (2003) - while they get different coefficients for variables across GMM and within group specifications, their conclusion about which countries have the higher coefficient is unchanged. 
Europe. Scarpetta, Hemmings, Tressel and Woo (2002) also show that rates of entry and exit at the national level are affected by regulation. Since entry and exit decisions take place mostly at the bottom of the size distribution, our results are somewhat different in that they look at investment, i.e. at already existing firms. Desai, Gompers and Lerner (2003) show that political, legal and regulatory variables affect entry and exit in emerging markets (i.e. Eastern Europe) but not in Western Europe. They also show some that these variables impact average size and the skewness of size distributions. Kumar, Rajan and Zingales (2001) find that firm size is increasing in various measures of financial development. Our results concern the determinant of investment, i.e. growth, rather than static size distribution of firms.

\subsection{Allocations}

Our findings on cross-firm investment allocations are complementary to research on cross-industry investment allocations. The latter have been shown to respond more to productivity differences when external financial markets are more developed. In particular, Wurgler (2000) shows that the cross-industry allocation of investment is more responsive to sector-level productivity in countries with better developed stock markets. These findings are consistent with our results, but do not concern within-industry allocations (we analyze how investment depends on cash flow and productivity holding industry fixed).

\subsection{Aggregate frictions}

Finally, our results shed light on research establishing a link between input market frictions and aggregate economic performance (see King and Levine (1993) and Rajan and Zingales (1998) regarding financial markets; Besley and Burgess (2004) for labor markets; see also Blanchard and Giavazzi (2004) for a model of product and labor market frictions). We provide new evidence on the costs of financial frictions, suggesting a channel for these aggregate effects.

\section{Predictions}

In this section, we summarize the theory behind our empirical research design. We analyze investment-cash flow sensitivities and compare their magnitude across countries. First, we test if on average, cash flow has a positive correlation with investment after controlling for industry-time-country interaction fixed effects as well as firm level controls. This would 
indicate some kind of constraints on the financing of firms or some kind of friction in financial markets.

In our tests, we will not use firm level $\mathrm{Q}$ (market to book value of assets) as a control. Measuring $Q$ is problematic for listed firms, and for all practical purposes impossible for nonlisted firms. Since our intent is to include the largest possible set of firms, we cannot hope to use $\mathrm{Q}$. To some extent we are reassured by the general finding in the literature that firm $\mathrm{Q}$ generally has a weak relation with investment. However, we do attempt to mitigate the possible omitted variable bias from not controlling for investment opportunities by including firm level variables. We use two specifications, both based on Bond et al (2003).

The first specification is based on an Euler equation derived from a dynamic optimization model, assuming a quadratic adjustment cost. The model does not yield neat closed form solutions and ideally requires knowledge of the firm specific rental rate of capital. Following Bond et al, we substitute industry-year fixed effects and log output to capital ratio to proxy for the unobserved rental rates. The regression equation is:

$$
I_{i, t}=\alpha_{1} I_{i, t-1}+\alpha_{2} I_{i, t-1}{ }^{2}+\alpha_{3}\left(\log Y_{i, t-1-1} \log K_{i, t-1}\right)+\alpha_{4} \operatorname{ROA}_{i, t-1}+\eta_{j, t}+\varepsilon_{i, t}
$$

where $I_{i, t}$, is gross investment normalized by fixed assets by firm $i$ in period $t$, ROA is EBITDA/Fixed Assets (same normalization as investment), $\mathrm{Y}_{\mathrm{i}, \mathrm{t}-1}$ is lagged output, $\mathrm{K}_{\mathrm{i}, \mathrm{t}-\mathrm{1}}$ is lagged capital and $\eta_{\mathrm{j}, \mathrm{t}}$ denotes industry-year fixed effects. Note that ROA based on cash flow before interest and taxes (EBITDA), not net cash flow. The reason for using EBITDA is that it is predicted by the Euler equation to enter (negatively). A positive coefficient can then be interpreted as signifying financial constraints. ${ }^{8}$ Hereafter we refer to the specification in Equation 1 as the Euler equation model.

The second model is derived by introducing second order (ADL $(2,2))$ dynamics into a static capital demand equation (obtained from profit maximization subject to constant returns to scale and a CES production function):

8 Since the EBITDA variable is closely correlated with cash flow measures, the results from this specification could be expected to be similar to those using the more traditional cash flow variable (see specification below). 


$$
\begin{aligned}
I_{i, t}=\alpha_{1} I_{i, t-1}+\alpha_{2}\left(\log Y_{i, t}-\log Y_{i, t-1}\right)+\alpha_{3}\left(\log Y_{i, t-1}-\log Y_{i, t-2}\right) & \\
& +\alpha_{4} \text { error }+\alpha_{5} C F_{i, t}+\alpha_{6} C F_{i, t-1}+\eta_{i, t}+\varepsilon_{i, t}
\end{aligned}
$$

where It and Yt are as defined in equation 1 above, error stands for the error correction term $\left(\log \mathrm{K}_{\mathrm{i}, \mathrm{t}-2}-\log \mathrm{Y}_{\mathrm{i}, \mathrm{t}-2)}\right)$. Hereafter, we refer to the specification in equation 2 as the Econometric model.

We examine the effect of financial development on constraints for investments by interacting the ROA term (in the Euler equation model) and the CF term (in the Econometric model) with a proxy for financial development. A negative (positive) coefficient on the interaction term would be interpreted as a indicating a decrease (increase) in financial constraints with financial development. ${ }^{9}$ In Section 5 below, we consider a number of extensions and robustness checks of our basic specifications.

\section{Data}

\subsection{Amadeus}

Our firm-level data is taken from Amadeus, a commercial database provided by Bureau van Dijk. It contains at least some financial information on over 7 million private and publicly owned firms across 38 European countries. The database includes up to 10 years of information per company and is created by collecting data from 35 information providers across Europe, generally the office of the Registrar of Companies, and standardizing it. We use a sample of larger firms, for which data quality and coverage is likely to be better than the smallest firms.

We use the 2004 edition of Amadeus for large and medium firms, including all firms with operating revenue of at least $€ 1 \mathrm{M}$, total assets of at least $€ 2 \mathrm{M}$ and 20 employees or more (for the UK, Germany, France, Italy, Ukraine and Russia the number are $€ 1.5 \mathrm{M}, € 3 \mathrm{M}$, and 20, respectively). This sample contains approximately $1.5 \mathrm{M}$ firms. We then limit our sample by

${ }^{9}$ In the appendix, we report results from running the basic specifications country-by-country and examining the coefficients against financial development. As discussed in the appendix, the regression of the estimated coefficients needs to adjust for the standard errors of the estimated cash flow coefficients. Since we cluster our standard errors at the country level, the standard error on the interaction specification implicitly adjusts for this. 
imposing the restriction that value added, capital and sales or turnover variables must be available. The database includes firm-level accounting data in standardized format for balance sheet and income statement items. Despite EU harmonization and international convergence in accounting standards and practices, there are differences in the accounting and these transformed accounts should therefore be interpreted with some caution. We use gross investment, defined as $\{$ (Fixed Assets in year $\mathrm{t}$ ) - (Fixed Assets in year $\mathrm{t}-1)+$ Depreciation $(\mathrm{t})\}$ divided by (Fixed assets in year $\mathrm{t}-1$ ).

Our cash flow variable is net income plus changes in deferred taxes, normalized by fixed assets (the same normalization as that used for investment). Profits are defined as EBITDA normalized by total assets. The cash flow and profit variables were winsorized at $0.5 \%$ and $99.5 \%$ to eliminate effects from extreme outliers.

In addition to financial information, Amadeus also provides other firm-level information. We use firm-level employment to measure labor inputs. Second, Amadeus provides various industry classifications - e.g. national industry codes, 3-digit European industry classification codes (NACE) and US NAICS codes - which we use to classify firms and construct industry dummy variables. In our analysis, we use 4-digit NAICS codes to construct industry dummies, and also categorize all firms by a 2-digit level NAICS code for industry interaction terms (see below). We classify firms as belonging to a conglomerate if Amadeus reports an ultimate holding company id number. ${ }^{10}$

The regular Amadeus files do not include banks, but it does include other financial firms. As one of our robustness checks, we exclude all firms classified as belonging to NAICS 52 and 53 (both finance and real estate).

10 Briefly, an ultimate owner is indicated as the largest shareholder company, if the largest shareholder company has at least $24.99 \%$ shareholding. If the immediate parent company is in turn owned by multiple companies, the ownership path is followed upward on the largest shareholding path. The upward trace is stopped when they reach a firm with no known single shareholder. Each trace upward is made only if a single shareholder has at least $24.99 \%$ holding. We only consider the existence of an ultimate owner, not that owner's identity. 


\subsection{Other data sources}

Finance. The ideal measure of financial development would capture the ability of firms with good investment opportunities (positive NPV) to find outside financing in case of need. Such a measure is difficult to come by across many countries, so we use two alternative measures, each of which has its strengths and weaknesses. Our two measures focus on banks on the one hand, and banks as well as debt markets on the other. Based on the financial database of Beck, Demirgüç-Kunt and Levine (2001), we calculate the total volume of bank credit to the private sector, divided by GDP. The number refers to 1995, ahead of almost all of our Amadeus firm observations. Secondly, we use the market value of all outstanding bonds + private credit, normalized by GDP, as a measure of financial market development. This measure is also from Beck et al (2001). By taking these variables to represent finance, we disregard the role of outside equity. However, for almost all firms in our sample, outside equity is likely to be very limited. Furthermore, different measures of financial development are highly correlated across countries. We have tried using broader measures of finance, including equity markets, but find that our results are very similar.

Asset liquidity. We use an industry-level measure of asset liquidity. We use US data to avoid endogeneity issues. Using this measure as a proxy for liquidity assumes that industries rank similarly in the European sample in terms of asset liquidity. This seems fairly innocuous since technological features of assets are likely to be fairly similar across different (rich) economies, but we cannot verify that it is correct.

Our liquidity measure is defined as sales of PPE (plant, property and equipment) divided by net PPE, aggregated at the industry level (4-digit NAICS). ${ }^{11}$ In order to make the measure capture time-invariant features of industry asset liquidity, we take averages for 198595 , the ten years preceding the sample of firm data we use. Alternatively, we have used an average spanning the 1971-2004 period, maximizing the amount of data, which gives very similar results (not reported). ${ }^{12}$

\footnotetext{
${ }^{11}$ We thank Efraim Benmelech for sharing this with us.

${ }^{12}$ We have also tried triple interactions of liquidity interacted with financial development and firm cash flow. The results are similar, but requires interpreting a larger number of coefficients.
} 


\subsection{Sample overview}

Following the practice in the literature, we restrict the sample to those with strictly positive investment i.e. drop firm observations for which gross investment is negative. Also, to avoid outliers we eliminate observations for which CF/A is larger than ten.

Table 1 reports financial variables for each country. We report two measures: private credit (later called PCBank) and private credit plus bond market capitalization (PCBB). As expected, richer countries tend to have higher values for both measures. Also, Western European countries tend to have the highest values. The highest numbers, corresponding to the most developed banking systems, are for Switzerland (1.66), Germany (1.14), Sweden (1.17) and the UK (1.14). Including the bond market does not change the rankings much: the correlation between the measures is 0.88 and the rank correlation is 0.84 . The levels are much higher in many countries, however, notably Switzerland (3.96), the UK (2.62) and the Netherlands (2.00).

Table 2 reports summary statistics across firms in our sample. We report three categories of variables: those used throughout, those used for the Euler equation model and those used for the econometric model. All-in-all there is about 1.9 million observations, though we often have fewer observations when all missing data is taken into account. The general variables are PCBank and PCBB, the conglomerate dummy, the number of employees, firm age and investment. Investment is 0.50 on average, and the median is 0.22 . There is a tail of considerably higher values. This may seem large, but note that the sample excludes all negative investment firms. Average firm age is approximately 17 years and half the firms are less than 12 years old. For the Euler Equation model, we use the following additional variables -- squared investment, lagged capital intensity and ROA (EBITDA over fixed assets). Profitability averages 0.116 and has a median of 0.105 . For the Econometric model, we also use the variables output growth, capital-output ratio and cash flow (after taxes and interest, normalized by fixed assets). Cash flow averages 0.589 and has a median of 0.304 .

\section{Results}

This section presents the basic regression of investment on contemporaneous cash flow and controls. As pointed out above, we cannot control for $\mathrm{Q}$ because most companies in our sample are unlisted. To control for desired investment (in the absence of frictions), we therefore employ two regression specifications as described in Section 2 above. We refer to these as the 
Euler equation model and the Econometric specification. For each table, we report two panels of results, one for each method.

Table 3 shows our basic regression: investment regressed on cash flow, firm level controls and country-industry-year dummies. For the Euler equation model, column (1) shows that cash flow enters with a positive and significant coefficient, which we interpret (subject to caveats discussed in Section 1.1) as reflecting financial constraints. The estimated effect on investment is small. Changing profits from the $25^{\text {th }}$ to the $75^{\text {th }}$ percentile implies that the right hand side variable is higher by 0.0448 , i.e. investment is higher by $4.5 \%$ of fixed capital. Increasing profits by one standard deviation increases investment by about a tenth of a standard deviation. Column (2) repeats the same regression for the sample of firms for which we have financial development data. Column (3) includes an interaction of financial development and firm level profits, using the broader measure of financial development PCBB. The regression shows that profits have a muted impact on investment in countries with higher financial development: the interaction coefficient is negative and significant. The negative coefficient suggests that financial constraints are less severe when there is better financial development. This is our main finding. The magnitude of this effect is large, and suggests that moving from the $25^{\text {th }}$ to the $75^{\text {th }}$ percentile of financial development (across firms) will reduce the effect of profits by about $27 \%$ (from 0.088 to 0.064 ). Column (4) represents the regression for the subset for which there is financial development data for the more restricted measure of financial development (PCBank) and column (5) presents a regression with PCBank interacted with firm level profits. The interaction for this measure is significant (but less so than the previous interaction) and slightly larger in magnitude. Here, moving from the $25^{\text {th }}$ to the $75^{\text {th }}$ percentile of financial development is estimated to reduce the effect of profits by approximately three quarters.

The second panel presents similar results for the Econometric model. The effect of profits and cash flow in this specification is smaller but also highly significant, suggesting that financial constraints are significant. Importantly, the interaction with financial development is negative and significant for $\mathrm{PCBB}$, here moving from the $25^{\text {th }}$ to the $75^{\text {th }}$ percentile of financial development reduces the effect of cash flow by approximately half. The result for PCBank is insignificant, i.e. in this specification, higher financial development does not reduce the cash- 
flow sensitivity of investment. This is in contrast to the Euler-equation results using PCBank and the results for both models using PCBB.

\section{Extensions and robustness}

This section presents a series of extensions and robustness tests. We have also tried restricting the sample to those country-industry-year cells which include 20 observations or more, and found very similar results, confirming that our results are not driven by outlier industries, countries or years (not reported).

\subsection{Conglomerates}

Hoshi, Kashyap, and Scharfstein (1991) find that firms that form part of a conglomerate have lower cash flow-investment sensitivities. ${ }^{13}$ We now test whether this is the case in our sample. Table 4, column (1) to (3), reproduce results from Table 3, i.e. our baseline specification, for both models. ${ }^{14}$ In columns (4) to (6), we restrict the sample to conglomerate firms, i.e. firms which have a specified large shareholder which is also a firm. Profits and cash flow seem to matter less for these firms, which is consistent with such firms having access to internal capital markets, or facing lower financing constraints for some other reason.

Our results suggest that financial development helps conglomerate firms, but less than non-conglomerate firms. The interactions with financial development are significant in all cases, but always lower than for non-conglomerate firms. ${ }^{15}$ On possible function of conglomerates is to finance investment using resources, reallocated through internal capital markets. If this makes individual divisions less dependent on the external finance, we expect financial development to

${ }^{13}$ See also Campello (2004) regarding internal capital markets and investment. Note that we look at the effect of subsidiary level cash flow on investment at the subsidiary level; results could differ for the effect of firm-level aggregate cash flow on investment at the subsidiary or firm level (see e.g. Lamont (1997) regarding conglomerate level cash flows and firm investment).

${ }^{14}$ From this point on, in order to save some space, we suppress the estimated coefficients for control variables and report only the coefficients for cash flow and the cash flow interactions.

${ }^{15}$ The difference between conglomerates and the overall sample is significant at the $5 \%$ level in all cases except the Econometric model using PCBank (where the difference is barely significant at the $10 \%$ level). 
matter less for divisions. Therefore this finding is consistent with the theory that financial development reduces financial constraints for firms that are more dependent on external capital markets. ${ }^{16}$

\subsection{Excluding financial and real estate firms}

Financial firms, as well as real estate firms, may have accounting data of a very different nature from other sectors which might affect results. While the Amadeus files do not contain banks, several firms are classified as belonging to NAICS 52 (Financial activities) or 53 (Real estate and rental and leasing). We exclude these firms, to make sure that they do not drive the main results of Table 3. In Table 5, we report profit and cash flow coefficients for the sub-sample without NAICS 52 and 53. The sample size is reduced marginally in both panels. The coefficients and significance is virtually unaffected by this exclusion, confirming that our results are general to the sample and not driven by the small number of financial firms and real estate firms.

\subsection{Western versus Eastern Europe}

Our sample covers the much richer Western European countries as well as the poorer Eastern countries. These have a much lower financial development as well as overall economic, regulatory, and political development. We now turn to a geographical split of our sample, to rule out the possibility that the financial development indicator matters simply because it separates Western European from Eastern European countries (Bulgaria, Croatia, Czech Republic, Hungary, Latvia, Poland, Romania, Slovenia, and Ukraine). By separating the samples, we test in effect whether the Portugal-Germany difference or the Latvia-Czech Republic difference affect cash flow coefficients, ignoring any differences between east and west.

Table 6 reports results allowing financial development to exert different effects in the two parts of Europe separately. Column (1) of both panels shows a regression with no interaction, recapping previous results. The rest of the regressions suggest two things. First, this

16 As Wolfenzon and Almeida (2006) point out, conglomerates may reduce financial constraints for divisions but still make finance more restricted for the central corporation through equilibrium effects. Our results are quiet about this prediction since we only include divisions in the regression in Table 4 . 
does not change our main inference: in all cases (the Euler Equation model as well as the Econometric model, PCBB as well as PCBank) cash flow exerts a smaller effect on investment when financial development is better, as in out overall cases. Second, the evidence for a different effect in Eastern Europe is weak at best, with three insignificant interactions (Panel 1, column (3) and (5) as well as Panel 2 column (3)) and one significant (Panel 2 column (5)) of unexpected sign and unreasonable magnitude. However, this result must be interpreted with great care. We cluster standard errors by country, being as conservative as possible, but this means that we essentially have as many observations as we have countries (when we evaluate the significance of the financial development interactions). With seven countries in Eastern Europe, our t-tests are unreliable, and clustered standard errors may be untrustworthy. Considering the differences between East and West is therefore fraught with difficulty arising from data limitations. Overall, we conclude that financial development improves financial constraints on investment for the sub-sample of Western European countries and that Eastern Europe is not likely to be different. ${ }^{17}$

\subsection{Asset liquidity}

If firms are often financially constrained, this may affect behavior particularly in industries where assets are bad collateral. We might expect industries with plenty of assets suitable for collateralization to be much less affected. To test this, we compare industries with more or less liquid assets. The advantage of using industry characteristics, as opposed to estimated of actual firm asset liquidity, is that we do not have to worry about endogeneity. For example, perhaps firms in poor financial development countries chose to have more liquid assets (to cope with poor availability of external finance). They may be more financially constrained, but in fact look like they should be less (they have lots of liquid assets!). Using an invariant, industry-based measure gets around this. Our liquidity is exogenous to firms, so if firms in low liquidity industries react more to financial development, we can interpret this as a causal relationship with more confidence.

17 Our results from undertaking a country-by-country analysis (see Appendix) confirm the general conclusion that investment constraints are lower in better developed financial markets. Subject to limitations of sample size, the result seems to hold true also for the sub-sample of Western European firms. 
Regressions by asset liquidity group are presented in Table 7 . We divide the sample by industry, based on our US data on used asset turnover. The sample of high liquidity firms are those in the industries with above the $50^{\text {th }}$ percentile of US asset turnover rates. There are slightly more firms in the low liquidity sample because industries are of uneven size.

Table 7, column (1) of both panels shows a regression with no interaction, recapping previous results. In panel 1, presenting the Euler Equation model, liquidity interactions are insignificant. This suggests that liquidity is not important for cash flow constraints, neither directly not indirectly through the effect of financial development. Panel 2, presenting the Econometric model, does suggest a role for liquidity. In both column (3) and (5) the liquidity triple interaction enters significantly and negatively. This suggests that the ameliorating effect of financial development (i.e. financial development $=>$ internal cash flow matters less) is weaker in high liquidity industries. In other words, firms in low liquidity industries are more affected by financial development than firms in high liquidity industries, as predicted.

\section{Conclusions}

In frictionless financial markets, investment does not depend on internal cash flows. In a large European data set, we find that firms invest more on average when they have higher cash flow. We contribute to the literature by testing formally if the coefficient on internal resources (cash flow) is related to a country's financial development. Comparing countries, we find that the cash flow effect is indeed stronger in countries with weaker financial development. This suggests that financial constraints are strongest when financial development is low.

The effect is weaker inside conglomerates and is probably not driven by the East-West difference. This is consistent with the idea that conglomerates ease internal financial constraints. Industries with few low liquid assets may experience bigger benefits of financial development (i.e. the cash flow coefficient is reduced more by financial development in low liquidity industries). However, the evidence for this is mixed.

Our findings suggest that financial frictions operate in Europe. They suggest that financial development is beneficial because it reduces financial constraints at the firm level and therefore relaxes the correlation between internal resources and investment. 


\section{References}

Abel A and E. Eberly, 2002, "Q theory without adjustment costs and cash flow effects without financing constraints", mimeo.

Almeida, Heitor and Daniel Wolfenzon, 2006, "Should business groups be dismantled? The equilibrium costs of efficient internal capital markets," Journal of Financial Economics 79 (1), 99-144.

Alti, Aydogan, 2003, "How Sensitive is Investment to Cash Flow When Financing is Frictionless", Journal of Finance, 58(2), 707-722.

Bartelsman, Eric J. and Mark Doms, 2000, “Understanding Productivity: Lessons from Longitudinal Microdata", Journal of Economic Literature, 38, 569-94.

Beck, Torsten, Asli Demirgüç-Kunt and Ross Levine, 2001, “The Financial Structure Database" in Demirgüç-Kunt, Asli, and Ross Levine, eds. Financial Structure and Economic Growth - A Cross-Country Comparison of Banks, Markets and Development, MIT Press, Cambridge, Massachusetts.

Beck, Thorsten, Asli Demirgüç-Kunt and Vojislav Maksimovic, 2002, "Financing patterns around the world: the role of institutions" World Bank Policy Research Working Paper 2905, October.

Besley, Timothy and Robin Burgess, 2004, "Can Labor Regulation Hinder Economic Performance? Evidence from India", Quarterly Journal of Economics, 119(1), 91-134.

Bertrand, Marianne, Antionette Schoar and David Thesmar, 2004, “Banking Deregulation and Industry Structure: Evidence from the French Banking Reforms of 1985", Working paper.

Bond, S., J.A. Elston, J. Mairesse, and B. Mulkay, 2003, “Financial Factors and Investment in Belgium, France, Germany, and the United Kingdom: A Comparison Using Company Panel Data", Review of Economics and Statistics, 85, 153-165.

Bond, S., and J. Van Reenen, 2006, "Microeconometric models of investment and employment", Forthcoming in J.J. Heckman and E.E. Leamer (eds) Handbook of Econometrics, Vol 6.

Blanchard, Olivier and Francesco Giavazzi, 2004, “The Macroeconomic Effects of Regulation and Deregulation in Goods and Labor Markets", Quarterly Journal of Economics, 118(3), 879-909. 
Campello, Murillo, 2004, "Internal Capital Markets in Financial Conglomerates: Evidence from Small Bank Responses to Monetary Policy", Journal of Finance, 57 (6), 2773-2805.

Cooper, R. and J. Ejarque, 2001, “Exhuming Q: Market power vs. capital market imperfections”, NBER working paper 8182.

Davis, Stephen and John Haltiwanger, 1999, "Gross Job Flows", in Handbook of Labor Economics: Voume 3B, ed. Orley Ashenfelter and David Card. North Holland pp. 2711 - 2805.

Demirgüç-Kunt, Asli and Vojislav Maksimovic, 1998, “Law, Finance and Firm Growth” Journal of Finance, December, 53(6), 2107 - 2137.

Desai, Mihir, Paul Gompers and Josh Lerner, 2003, “Institutions, Capital Constraints and Entrepreneurial Firm Dynamics: Evidence from Europe", NBER working paper 10165.

Diamond, Douglas and Raghuram Rajan, 2000, "A Theory of Bank Capital”, Journal of Finance, December, 55(6), 2431-2465.

Fazzari, Steven, Glenn Hubbard and Bruce Petersen, 1988, "Financing constraints and corporate investment", Brookings Paper on Economic Activity, 1, 141-195.

Gomes, J., 2001, Financing investment, American Economic Review, Vol 91(5), pp 1263-1285.

Kaplan, Steven and Luigi Zingales, 1997, “Do investment-cash flow sensitivities provide useful measures of financing constraints?", Quarterly Journal of Economics, 112, 169-215.

Foster, Lucia, John Haltiwanger and C.J. Krizan, 1997, “Aggregate Employment Dynamics: Building from Microeconomic Evidence", American Economic Review, 87(1), 115-137.

Heckman, James J. and Carmen Pages, 2000, “The Cost of Job Security Regulation: Evidence from Latin American Labor Markets", NBER working paper 7773.

Hoshi, Takeo, Anil Kashyap and David Scharfstein, 1991, "Corporate structure, liquidity and investment: Evidence from Japanese panel data", Quarterly Journal of Economics, 106, 3360.

King, Robert G. and Levine, Ross, 1993, "Finance and Growth: Schumpeter Might Be Right", Quarterly Journal of Economics, August, 108(3), 681-737.

Kumar, Krishna V., Raghuram Rajan and Luigi Zingales, 2001, "What determines firms size?", CRSP Working Paper No. 496.

Moyen, Nathalie, 2004, "Investment-Cash Flow Sensitivities: Constrained versus Unconstrained Firms", Journal of Finance, 59(5), 2061-2092. 
Myers, Stewart C. and Raghuram G. Rajan, 1998, "The Paradox of Liquidity", The Quarterly Journal of Economics, Vol. 113, No. 3., August, 733-771.

Petersen, Mitchell and Raghuram G. Rajan, 1995, “The Effect of Credit Market Competition on Firm-Creditor Relationships," Quarterly Journal of Economics, 110, 407-443.

Rajan, Raghuram, 1992, “Insiders and Outsiders: The Choice between Informed and Arm'slength Debt", Journal of Finance, September, 67(4), 1367-1400.

Rajan, Raghuram and Luigi Zingales. "Financial Development and Growth" American Economic Review, June 1998, 88, 559-586.

Roberts, Mark J. and James R. Tybout, eds. 1996. Industrial Evolution in Developing Countries. Oxford University Press.

Scarpetta, Stefano, Philip Hemmings, Thierry Tressel and Jaejoon Woo, 2002, "The Role of Policy and Institutions for Productivity and Firm Dynamics: Evidence from Micro and Industry data", OECD working paper 329.

Wurgler, Jeffrey, 2000, "Financial markets and the allocation of capital", Journal of Financial Economics, 58, 187-214. 


\section{Table 1 - Financial development across countries}

This table summarizes two measure of financial development for sample countries. All numbers are averaged across available years for 1995-2003, and are taken from the Structural Database (Beck 2001). Private credit is the total value of credit from banks to the private sector, divided by GDP. Private credit \& private bonds is the sum of private credit and total private bond market capitalization divided by GDP.

\begin{tabular}{|c|c|c|c|}
\hline Country & Country Code & $\begin{array}{l}\text { Private credit 1995-2003 } \\
\text { average (PCBank) }\end{array}$ & $\begin{array}{c}\text { Private credit plus } \\
\text { private bonds } 1988 \\
\text { (PCBB) }\end{array}$ \\
\hline Austria & AT & . & 1.33 \\
\hline $\begin{array}{l}\text { Bosnia- } \\
\text { Herzegovina }\end{array}$ & BA & . & . \\
\hline Belgium & $\mathrm{BE}$ & & 1.24 \\
\hline Bulgaria & BG & 0.06 & . \\
\hline Switzerland & $\mathrm{CH}$ & 1.66 & 2.06 \\
\hline $\begin{array}{l}\text { Serbia And } \\
\text { Montenegro }\end{array}$ & CS & $\cdot$ & . \\
\hline Cyprus & $\mathrm{CY}$ & . & . \\
\hline Czech Republic & $\mathrm{CZ}$ & 0.68 & 0.59 \\
\hline Germany & DE & 1.14 & 1.68 \\
\hline Denmark & DK & 0.33 & 1.79 \\
\hline Estonia & $\mathrm{EE}$ & 0.24 & . \\
\hline Spain & ES & 0.81 & 1.04 \\
\hline Finland & FI & 0.51 & 0.81 \\
\hline France & FR & & . \\
\hline United Kingdom & GB & 1.16 & 1.51 \\
\hline Greece & GR & & 0.46 \\
\hline Croatia & HR & 0.38 & . \\
\hline Hungary & HU & 0.23 & 0.29 \\
\hline Eire & IE & 0.83 & 0.96 \\
\hline Iceland & IS & 0.64 & . \\
\hline Italy & IT & 0.57 & 1.01 \\
\hline Liechtenstein & LI & . & . \\
\hline Luxemburg & LU & . & . \\
\hline Latvia & LV & 0.12 & 0.17 \\
\hline Monaco & MC & . & . \\
\hline Macedonia & MK & . & . \\
\hline Malta & MT & 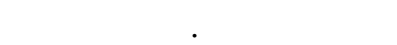 & . \\
\hline Netherlands & NL & 0.70 & 1.82 \\
\hline Norway & NO & 0.86 & 1.04 \\
\hline Poland & PL & 0.22 & . \\
\hline Portugal & PT & 0.88 & 1.29 \\
\hline Romania & $\mathrm{RO}$ & 0.09 & . \\
\hline Sweden & SE & 1.17 & 1.37 \\
\hline Slovenia & SI & 0.29 & . \\
\hline Ukraine & UA & 0.05 & . \\
\hline
\end{tabular}




\section{Table 2 - Summary statistics}

Summary statistics for key variables for the basic models, the Euler equation model and the Econometric model. Investment is normalized by fixed assets in the previous year. PCBank is private credit and PCBB is private credit plus bond market capitalization, both divided by GDP. Cash flow is defined by Amadeus (the data sources) and corresponds to net income plus depreciation plus changes in deferred taxes.

\begin{tabular}{lcccccccc} 
Variable & $\mathbf{N}$ & Mean & $\begin{array}{c}\text { St. } \\
\text { Dev. }\end{array}$ & p10 & p25 & $\begin{array}{c}\text { Medi } \\
\text { an }\end{array}$ & p75 & P90 \\
\hline PCBank & $1,879,691$ & 0.820 & 0.332 & 0.330 & 0.570 & 0.810 & 1.140 & 1.160 \\
PCBB & $1,879,691$ & 1.454 & 0.661 & 0.750 & 0.930 & 1.370 & 1.570 & 2.620 \\
Conglomerate dummy & $1,834,346$ & 0.165 & 0.371 & 0.0 & 0.0 & 0.0 & 0.0 & 1.0 \\
Number of employees & $2,111,378$ & 172.7 & 2280.2 & 9.0 & 15.0 & 30.0 & 73.0 & 210.0 \\
Firm age & $2,401,227$ & 17.198 & 17.917 & 3.0 & 6.0 & 12.0 & 22.0 & 37.0 \\
Investment & $1,128,477$ & 0.500 & 0.908 & 0.029 & 0.083 & 0.220 & 0.518 & 1.132 \\
Lagged Investment & 813,484 & 0.511 & 0.914 & 0.031 & 0.089 & 0.230 & 0.535 & 1.156
\end{tabular}

Variables used in the Euler equation model

Square of lagged investment Lagged output to capital ratio

813,484

$\begin{array}{ll}1.097 & 5.622 \\ 1.933 & 1.748\end{array}$

0.001

$-0.063$

0.008

0.053

0.286

$1,416,848$

0.78

1.45

0.02

0.17

$1.986-2.990$

1.337

$1,292,284$

Variables used in

Econometric model

Change in output

Lagged change in output

Twice lagged capital to

output ratio (error correction)

Cash flow/capital

Lagged cash flow/capital

$\begin{array}{cccccccc}1,702,770 & 0.098 & 0.492 & -0.163 & -0.025 & 0.051 & 0.177 & 0.391 \\ 1,151,866 & 0.112 & 0.471 & -0.139 & -0.015 & 0.060 & 0.187 & 0.400 \\ & & & & & & & \\ 954,973 & -1.953 & 1.705 & -3.908 & -2.989 & -2.002 & -1.047 & -0.011 \\ 1,310,226 & 0.595 & 1.302 & 0.000 & 0.121 & 0.305 & 0.694 & 1.606 \\ 1,255,517 & 0.589 & 1.297 & -0.001 & 0.120 & 0.304 & 0.689 & 1.588\end{array}$




\section{Table 3 - Investment and cash flow: the effect of financial development}

Dependent variable in all regressions is gross investment (normalized by assets). ROA is defined as operating cash flow over fixed assets, and cash flow is defined as cash flow after taxes and interest over fixed assets. PCBank is the average for the 1995-2003 period of the ratio of the total stock of credit to the private sector to GDP. PCBB is the average for the 1995-2003 period of the sum of private credit and total private bond market capitalization divided by GDP. Column 1 uses all observations. Column 2 and 6 uses observations only for countries for which the relevant financial development variable is available (in column 2, PCBB, in column 6, PCBank). Column 4 and 7 exclude Switzerland. All regressions include fixed effects for country-year-industry interactions. Standard errors are clustered by country-industry-year in column 1 and by country in other columns. A plus sign (+) denotes a significant coefficient at the $10 \%$ level, one star $\left(^{*}\right)$ denotes significance at the $5 \%$ level, two stars at the $1 \%$ level.

\begin{tabular}{|c|c|c|c|c|c|c|c|}
\hline $\begin{array}{l}\text { Euler equation } \\
\text { model }\end{array}$ & (1) & (2) & (3) & (4) & (5) & (6) & (7) \\
\hline Sample & All obs. & $\begin{array}{l}\text { PCBB } \\
\text { sample }\end{array}$ & $\begin{array}{l}\text { PCBB } \\
\text { sample }\end{array}$ & $\begin{array}{l}\text { Excluding } \\
\text { CHE }\end{array}$ & $\begin{array}{l}\text { PCBank } \\
\text { sample }\end{array}$ & $\begin{array}{l}\text { PCBank } \\
\text { sample }\end{array}$ & $\begin{array}{l}\text { Excluding } \\
\text { CHE }\end{array}$ \\
\hline \multirow[t]{2}{*}{ Lagged investment } & $0.161^{* *}$ & $0.159^{* *}$ & $0.158^{* *}$ & $0.158^{* *}$ & $0.161^{* *}$ & $0.16^{* *}$ & $0.16^{* *}$ \\
\hline & {$[0.003]$} & {$[0.014]$} & {$[0.014]$} & {$[0.014]$} & {$[0.011]$} & {$[0.011]$} & {$[0.011]$} \\
\hline \multirow{2}{*}{$\begin{array}{l}\text { Lagged investment } \\
\text { squared }\end{array}$} & $-0.017^{* *}$ & $-0.017^{* *}$ & $-0.017^{* *}$ & $-0.017^{* *}$ & $-0.017^{* *}$ & $-0.017^{* *}$ & $-0.017^{\star *}$ \\
\hline & {$[0.001]$} & {$[0.002]$} & {$[0.002]$} & {$[0.002]$} & {$[0.001]$} & {$[0.001]$} & {$[0.001]$} \\
\hline \multirow{2}{*}{$\begin{array}{l}\text { Lagged output- } \\
\text { capital ratio }\end{array}$} & $0.131^{* *}$ & $0.134^{* *}$ & $0.131^{* *}$ & $0.131^{* *}$ & $0.132^{* *}$ & $0.129^{* *}$ & $0.129^{* *}$ \\
\hline & {$[0.002]$} & {$[0.008]$} & {$[0.009]$} & {$[0.009]$} & {$[0.006]$} & [0.007] & {$[0.007]$} \\
\hline \multirow[t]{2}{*}{ Lagged ROA } & $0.059^{* *}$ & $0.062^{* *}$ & $0.122^{* *}$ & $0.122^{* *}$ & $0.059^{* *}$ & $0.098^{\star *}$ & $0.098^{* *}$ \\
\hline & {$[0.002]$} & [0.015] & {$[0.018]$} & {$[0.018]$} & {$[0.010]$} & [0.013] & {$[0.013]$} \\
\hline Lagged ROA x & & & $-0.037^{* *}$ & $-0.037^{* *}$ & & & \\
\hline PCBB & & & {$[0.011]$} & {$[0.011]$} & & & \\
\hline Lagged ROA x & & & & & & $-0.096^{* *}$ & $-0.096^{* *}$ \\
\hline PCBank & & & & & & {$[0.026]$} & {$[0.026]$} \\
\hline R-squared & 0.12 & 0.13 & 0.13 & 0.13 & 0.12 & 0.12 & 0.12 \\
\hline Observations & 639,205 & 468,832 & 468,832 & 468,345 & 636,642 & 636,642 & 636,053 \\
\hline Number of clusters & 12,200 & 21 & 21 & 20 & 18 & 18 & 18 \\
\hline
\end{tabular}




\section{Table 3 continued}

\begin{tabular}{|c|c|c|c|c|c|c|c|}
\hline Econometric model & (1) & $(2)$ & (3) & $(4)$ & (5) & (6) & (7) \\
\hline Sample & All obs. & $\begin{array}{c}\text { PCBB } \\
\text { sample }\end{array}$ & $\begin{array}{c}\text { PCBB } \\
\text { sample }\end{array}$ & $\begin{array}{c}\text { Excluding } \\
\text { CHE }\end{array}$ & $\begin{array}{l}\text { PCBank } \\
\text { sample }\end{array}$ & $\begin{array}{c}\text { PCBank } \\
\text { sample }\end{array}$ & $\begin{array}{c}\text { Excluding } \\
\text { CHE }\end{array}$ \\
\hline \multirow[t]{2}{*}{ Lagged investment } & 0.005 & 0.001 & 0.001 & 0.001 & 0.006 & 0.006 & 0.006 \\
\hline & {$[0.007]$} & {$[0.007]$} & {$[0.007]$} & [0.007] & {$[0.007]$} & {$[0.007]$} & {$[0.007]$} \\
\hline \multirow[t]{2}{*}{ Change in output } & $0.26^{* *}$ & $0.24^{* *}$ & $0.236^{* *}$ & $0.236^{* *}$ & $0.257^{* *}$ & $0.255^{* *}$ & $0.255^{* *}$ \\
\hline & {$[0.010]$} & {$[0.027]$} & {$[0.026]$} & {$[0.026]$} & {$[0.033]$} & {$[0.033]$} & {$[0.033]$} \\
\hline \multirow[t]{2}{*}{ Lagged change in output } & $0.194^{* *}$ & $0.199^{* *}$ & $0.195^{* *}$ & $0.195^{* *}$ & $0.190^{* *}$ & $0.188^{* *}$ & $0.188^{* *}$ \\
\hline & {$[0.005]$} & {$[0.007]$} & {$[0.006]$} & {$[0.006]$} & {$[0.006]$} & {$[0.005]$} & {$[0.005]$} \\
\hline \multirow[t]{2}{*}{ Error correction } & $-0.135^{* *}$ & $-0.141^{* *}$ & $-0.139^{* *}$ & $-0.139^{* *}$ & $-0.131^{* *}$ & $-0.131^{* *}$ & $-0.131^{* *}$ \\
\hline & {$[0.002]$} & {$[0.008]$} & {$[0.009]$} & {$[0.009]$} & {$[0.008]$} & {$[0.008]$} & {$[0.008]$} \\
\hline \multirow[t]{2}{*}{ Cash Flow } & $0.079^{* *}$ & $0.087^{* *}$ & $0.183^{* *}$ & $0.183^{* *}$ & $0.075^{* *}$ & $0.087^{* *}$ & $0.087^{* *}$ \\
\hline & {$[0.004]$} & {$[0.030]$} & {$[0.042]$} & {$[0.042]$} & {$[0.023]$} & {$[0.023]$} & {$[0.023]$} \\
\hline \multirow[t]{2}{*}{ Lagged cash flow } & $0.017^{* *}$ & $0.014^{* *}$ & $0.015^{*}$ & $0.015^{*}$ & $0.018^{* *}$ & $0.018^{* *}$ & $0.018^{* *}$ \\
\hline & {$[0.065]$} & {$[0.07]$} & {$[0.007]$} & {$[0.007]$} & {$[0.006]$} & {$[0.006]$} & {$[0.006]$} \\
\hline \multirow[t]{2}{*}{ Cash Flow $x$ PCBB } & & & $-0.06^{* *}$ & $-0.06^{* *}$ & & & \\
\hline & & & {$[0.019]$} & {$[0.019]$} & & & \\
\hline \multirow[t]{2}{*}{ Cash Flow x PCBank } & & & & & & 0.098 & 0.098 \\
\hline & & & & & & {$[0.065]$} & {$[0.065]$} \\
\hline R-squared & 0.13 & 0.14 & 0.14 & 0.14 & 0.12 & 0.12 & 0.12 \\
\hline Observations & 503,660 & 370,675 & 370,660 & 370,298 & 469,436 & 469,436 & 469,059 \\
\hline Number of clusters & 9,542 & 20 & 20 & 19 & 17 & 17 & 16 \\
\hline
\end{tabular}




\section{Table 4 - Conglomerates}

Dependent variable is gross investment (normalized by assets). Column 1-3 use all observations, columns 4-6 conglomerate firms only. Coefficients for control variables (see table 3) are not reported. All regressions include fixed effects for country-year-industry interactions. Standard errors are clustered by country. A plus sign (+) denotes a significant coefficient at the $10 \%$ level, one star $\left(^{*}\right)$ denotes significance at the $5 \%$ level, two stars at the $1 \%$ level.

\begin{tabular}{|c|c|c|c|c|c|c|}
\hline Euler equation model & (1) & (2) & (3) & $(4)$ & $(5)$ & (6) \\
\hline Sample & All & All & All & Congl. & Congl. & Congl. \\
\hline \multirow[t]{2}{*}{ Lagged ROA } & $0.059^{*}$ & $0.122^{*}$ & $0.098^{* *}$ & $0.024^{* *}$ & $0.056^{* *}$ & $0.050^{* *}$ \\
\hline & {$[0.010]$} & {$[0.018]$} & {$[0.013]$} & {$[0.005]$} & {$[0.15]$} & [0.012] \\
\hline \multirow[t]{2}{*}{ Lagged ROA x PCBB } & & $-0.037^{* *}$ & & & $-0.014^{*}$ & \\
\hline & & {$[0.011]$} & & & {$[0.007]$} & \\
\hline \multirow[t]{2}{*}{ Lagged ROA x PCBank } & & & $-0.096^{* *}$ & & & $-0.043^{*}$ \\
\hline & & & {$[0.026]$} & & & {$[0.017]$} \\
\hline R-squared & 0.12 & 0.13 & 0.16 & 0.16 & 0.17 & 0.16 \\
\hline Observations & 636,642 & 468,832 & 636,642 & 91,525 & 71,186 & 91,525 \\
\hline Number of clusters & 25 & 21 & 25 & 25 & 21 & 25 \\
\hline Econometric model & (1) & (2) & (3) & $(4)$ & (5) & (6) \\
\hline Sample & All & All & All & Congl. & Congl. & Congl. \\
\hline \multirow[t]{2}{*}{ Cash Flow } & $0.017^{* *}$ & $0.183^{* *}$ & $0.13^{* *}$ & $0.021^{+}$ & $0.067^{*}$ & $0.061^{* *}$ \\
\hline & {$[0.065]$} & {$[0.042]$} & {$[0.030]$} & {$[0.011]$} & [0.027] & {$[0.020]$} \\
\hline \multirow[t]{2}{*}{ Cash Flow x PCBB } & & $-0.060^{* *}$ & & & $-0.02^{+}$ & \\
\hline & & {$[0.019]$} & & & {$[0.012]$} & \\
\hline \multirow[t]{2}{*}{ Cash Flow x PCBank } & & & $-0.148^{* *}$ & & & $-0.068^{*}$ \\
\hline & & & {$[0.044]$} & & & {$[0.024]$} \\
\hline R-squared & 0.13 & 0.14 & 0.07 & 0.17 & 0.18 & 0.17 \\
\hline Observations & 503,660 & 370,675 & 501,167 & 70,149 & 54,249 & 70,149 \\
\hline Number of clusters & 9,542 & 20 & 25 & 23 & 19 & 23 \\
\hline
\end{tabular}




\section{Table 5 - Excluding finance and real estate}

Dependent variable is gross investment (normalized by assets). Firms with primary industry classification NAICS 52 or 53 are excluded. Coefficients for control variables (see table 3) are not reported. All regressions include fixed effects for country-year-industry interactions. Standard errors are clustered by country-industry-year in column 2 and 3 and by country in other columns. A plus sign $(+)$ denotes a significant coefficient at the $10 \%$ level, one star $\left(^{*}\right)$ denotes significance at the $5 \%$ level, two stars at the $1 \%$ level.

\begin{tabular}{|c|c|c|c|}
\hline Euler equation model & (1) & (2) & (3) \\
\hline Sample & \multicolumn{3}{|c|}{ Non-financial, non-real estate firms } \\
\hline \multirow[t]{2}{*}{ Lagged ROA } & $0.059^{* *}$ & $0.121^{* *}$ & $0.065^{* *}$ \\
\hline & {$[0.002]$} & {$[0.019]$} & {$[0.008]$} \\
\hline \multirow[t]{2}{*}{ Lagged ROA x PCBB } & & $-0.037^{* *}$ & \\
\hline & & {$[0.012]$} & \\
\hline \multirow[t]{2}{*}{ Lagged ROA x PCBank } & & & $-0.066^{+}$ \\
\hline & & & {$[0.038]$} \\
\hline R-squared & 0.12 & 0.13 & 0.11 \\
\hline Observations & 639,208 & 454,117 & 583,300 \\
\hline Number of clusters & 12,220 & 21 & 18 \\
\hline Econometric model & (1) & $(2)$ & (3) \\
\hline Sample & & al, non-rea & \\
\hline \multirow[t]{2}{*}{ Cash Flow } & $0.079^{* *}$ & $0.184^{* *}$ & $0.138^{* *}$ \\
\hline & {$[0.004]$} & {$[0.043]$} & [0.030] \\
\hline \multirow[t]{2}{*}{ Cash Flow x PCBB } & & $-0.061^{* *}$ & \\
\hline & & {$[0.020]$} & \\
\hline \multirow[t]{2}{*}{ Cash Flow x PCBank } & & & $-0.15^{* *}$ \\
\hline & & & [0.045] \\
\hline R-squared & 0.13 & 0.14 & 0.13 \\
\hline Observations & 503,660 & 359,184 & 485,533 \\
\hline Number of clusters & 9,542 & 20 & 25 \\
\hline
\end{tabular}




\section{Table 6 - Geographical subsamples}

Dependent variable is gross investment (normalized by assets). Coefficients for control variables (see table 3) are not reported. All regressions include fixed effects for country-year-industry interactions. Standard errors are clustered by country-industry-year in column 1 and 4 and by country in other columns. A plus sign $(+)$ denotes a significant coefficient at the $10 \%$ level, one star $\left(^{*}\right)$ denotes significance at the $5 \%$ level, two stars at the $1 \%$ level.

\begin{tabular}{|c|c|c|c|c|c|}
\hline Euler equation model & (1) & (2) & (3) & (4) & (5) \\
\hline Sample & & & All & & \\
\hline \multirow[t]{2}{*}{ Lagged ROA } & $0.059^{* *}$ & $0.122^{* *}$ & $0.120^{* *}$ & $0.066^{* *}$ & $0.100^{* *}$ \\
\hline & {$[0.020]$} & {$[0.018]$} & {$[0.020]$} & {$[0.008]$} & {$[0.016]$} \\
\hline \multirow[t]{2}{*}{ Lagged ROA x PCBB } & & $-0.037^{* *}$ & $-0.036^{* *}$ & & \\
\hline & & {$[0.011]$} & {$[0.012]$} & & \\
\hline \multirow[t]{2}{*}{ Lagged ROA x PCBank } & & & & $-0.068^{+}$ & $-0.100^{* *}$ \\
\hline & & & & {$[0.038]$} & {$[0.031]$} \\
\hline \multirow[t]{2}{*}{ Lagged ROA $\times$ East } & & & -0.015 & & 0.042 \\
\hline & & & {$[0.041]$} & & [0.046] \\
\hline \multirow[t]{2}{*}{ Lagged ROA x PCBB X East } & & & 0.048 & & \\
\hline & & & {$[0.036]$} & & \\
\hline \multirow[t]{2}{*}{ Lagged ROA x PCBank X East } & & & & & 0.292 \\
\hline & & & & & {$[0.184]$} \\
\hline R-squared & 0.12 & 0.13 & 0.13 & 0.11 & 0.12 \\
\hline Observations & 639,208 & 468,832 & 468,832 & 602,175 & 636,642 \\
\hline Number of clusters & 12,220 & 21 & 21 & 18 & 26 \\
\hline
\end{tabular}


Econometric model

Sample

Cash Flow

Cash Flow x PCBB

Cash Flow x PCBank

Cash Flow x East

Cash Flow x PCBB X East

Cash Flow x PCBank X East

R-squared

Observations

Number of clusters
(1)

(2)

(3)

(4)

(5)

All firms

\begin{tabular}{lll}
\hline & & \\
& & \\
{$[0.079 * *$} & $\mathbf{0 . 1 8 3 * *}$ & $\mathbf{0 . 1 8 2 * *}$ \\
& {$[0.042]$} & {$[0.053]$} \\
& & \\
& $-\mathbf{0 . 0 6 * *}$ & $-\mathbf{0 . 0 6} \mathbf{6}^{*}$ \\
& {$[0.019]$} & {$[0.024]$}
\end{tabular}

[0.072]

$\begin{array}{ll}-\mathbf{0 . 1 4 8 * *} & -\mathbf{0 . 1 6 0 *} \\ {[0.044]} & {[0.062]}\end{array}$

$-0.018$

$-0.102$

[0.069]

0.051

[0.067]
0.686 *

[0.260]

0.13

0.14

0.14

0.13

0.14

503,660

370,675

370,675

500,725

501,167

9,542

20

23 


\section{Table 7 - Asset liquidity subsamples}

Dependent variable is gross investment (normalized by assets). Coefficients for control variables (see table 3) are not reported. Hi_Liq is a dummy equal to one for all firms whose main industry is classified as having highly liquid assets. All regressions include fixed effects for country-year-industry interactions. Standard errors are clustered by country-industry-year in column 1 and 4 and by country in other columns. A plus sign $(+)$ denotes a significant coefficient at the $10 \%$ level, one star $\left(^{*}\right)$ denotes significance at the $5 \%$ level, two stars at the $1 \%$ level.

\begin{tabular}{|c|c|c|c|c|c|}
\hline Euler equation model & (1) & (2) & (3) & (4) & (5) \\
\hline Sample & & & All & & \\
\hline \multirow[t]{2}{*}{ Lagged ROA } & $0.059 * *$ & $0.122 * *$ & $0.120^{* *}$ & $0.066^{* *}$ & $0.098^{* *}$ \\
\hline & {$[0.020]$} & {$[0.018]$} & [0.039] & {$[0.008]$} & [0.018] \\
\hline \multirow[t]{2}{*}{ Lagged ROA x PCBB } & & $-0.037^{* *}$ & -0.065 & & \\
\hline & & {$[0.011]$} & {$[0.051]$} & & \\
\hline \multirow[t]{2}{*}{ Lagged ROA x PCBank } & & & & $-0.068^{+}$ & $-0.091^{*}$ \\
\hline & & & & {$[0.038]$} & [0.035] \\
\hline \multirow[t]{2}{*}{ Lagged ROA x Hi_Liq } & & & -0.007 & & 0.002 \\
\hline & & & {$[0.020]$} & & {$[0.011]$} \\
\hline \multicolumn{6}{|l|}{ Lagged ROA x PCBB X } \\
\hline \multirow[t]{2}{*}{ Hi_Liq } & & & -0.065 & & \\
\hline & & & {$[0.051]$} & & \\
\hline \multicolumn{6}{|l|}{ Lagged ROA x PCBank X } \\
\hline \multirow[t]{2}{*}{ Hi_Liq } & & & & & 0.004 \\
\hline & & & & & {$[0.018]$} \\
\hline R-squared & 0.12 & 0.13 & 0.14 & 0.11 & 0.12 \\
\hline Observations & 639,208 & 468,832 & 226,589 & 602,175 & 636,642 \\
\hline Number of clusters & 12,220 & 21 & 21 & 18 & 26 \\
\hline
\end{tabular}


Econometric model

Sample

Cash Flow

Cash Flow x PCBB

Cash Flow x PCBank

Cash Flow x Hi_Liq

Cash Flow x PCBB X Hi_Liq

Cash Flow x PCBank X

Hi_Liq

(1)

(2)

(3)

(4)

(5)

All firms

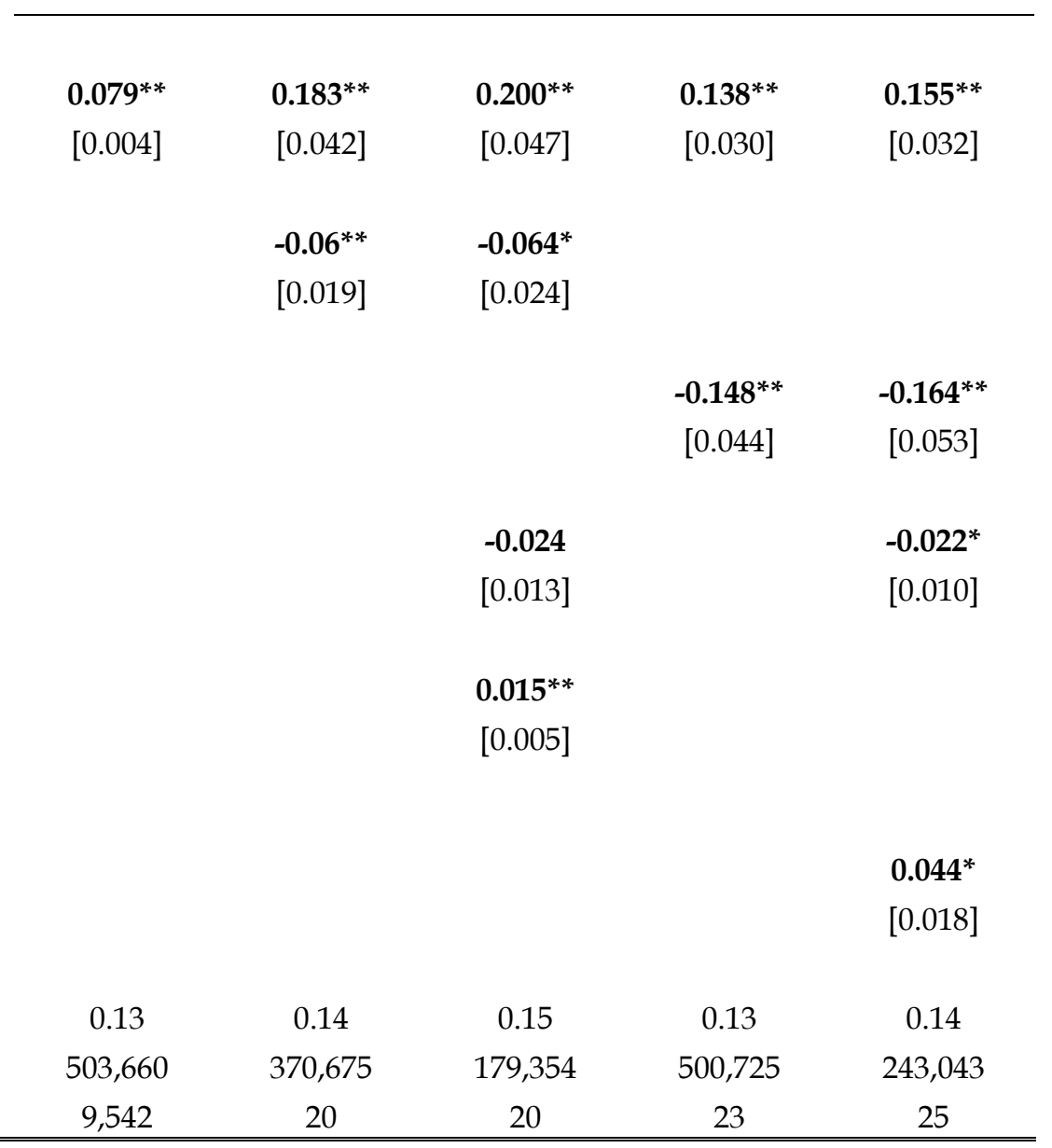




\section{Appendix: results from running the Euler equation model and Econometric model separately by country}

\section{Table A.1: Country wise results for the Euler equation model}

Dependent variable in all regressions is gross investment (normalized by assets). ROA is defined as operating cash flow over fixed assets. All regressions include the firm level variables and industry-year fixed effects used in the Euler equation model specifications in Table 1 (see text). Standard errors are clustered by industry-year. A plus sign $(+)$ denotes a significant coefficient at the $10 \%$ level, one star $\left(^{*}\right)$ denotes significance at the $5 \%$ level, two stars at the $1 \%$ level.

\begin{tabular}{lcc}
\hline \hline Country Name & $\begin{array}{c}\text { Lagged ROA } \\
\text { Coefficient }\end{array}$ & $\begin{array}{c}\text { Lagged ROA } \\
\text { Standard Error }\end{array}$ \\
\hline \hline Austria & 0.056 & {$[0.114]$} \\
Bosnia And Herzegovina & 0.208 & {$[0.232]$} \\
Belgium & $0.049^{* *}$ & {$[0.006]$} \\
Bulgaria & $0.077^{* *}$ & {$[0.022]$} \\
Switzerland & -0.015 & {$[0.037]$} \\
Serbia And Montenegro & $0.12^{* *}$ & {$[0.040]$} \\
Czech Republic & $0.092^{*}$ & {$[0.038]$} \\
Germany & 0.013 & {$[0.022]$} \\
Denmark & 0.026 & {$[0.022]$} \\
Estonia & $0.077^{* *}$ & {$[0.019]$} \\
Spain & $0.087^{* *}$ & {$[0.005]$} \\
Finland & $0.06^{* *}$ & {$[0.008]$} \\
France & $0.053^{* *}$ & {$[0.004]$} \\
United Kingdom & $0.019^{* *}$ & {$[0.003]$} \\
Greece & $0.073^{* *}$ & {$[0.007]$} \\
Croatia & $0.132^{* *}$ & {$[0.016]$} \\
Hungary & -0.127 & {$[0.205]$} \\
Italy & $0.095^{* *}$ & {$[0.005]$} \\
Luxembourg & -0.063 & {$[0.049]$} \\
Latvia & 0.235 & {$[0.377]$} \\
Netherlands & $0.036^{*}$ & {$[0.014]$} \\
Norway & $0.048^{* *}$ & {$[0.007]$} \\
Poland & $0.045^{* *}$ & {$[0.012]$} \\
Portugal & 0.033 & {$[0.039]$} \\
Sweden & $0.071^{* *}$ & {$[0.007]$} \\
Ukraine & $0.089^{* *}$ & {$[0.028]$} \\
\hline \hline
\end{tabular}




\section{Figure A.1: Constraints versus financial development (Euler equation model)}

This figure plots the coefficients on lagged ROA from the Euler equation model versus PCBB, for countries where the coefficient is significant. PCBB is the sum of private credit and total private bond market capitalization divided by GDP.

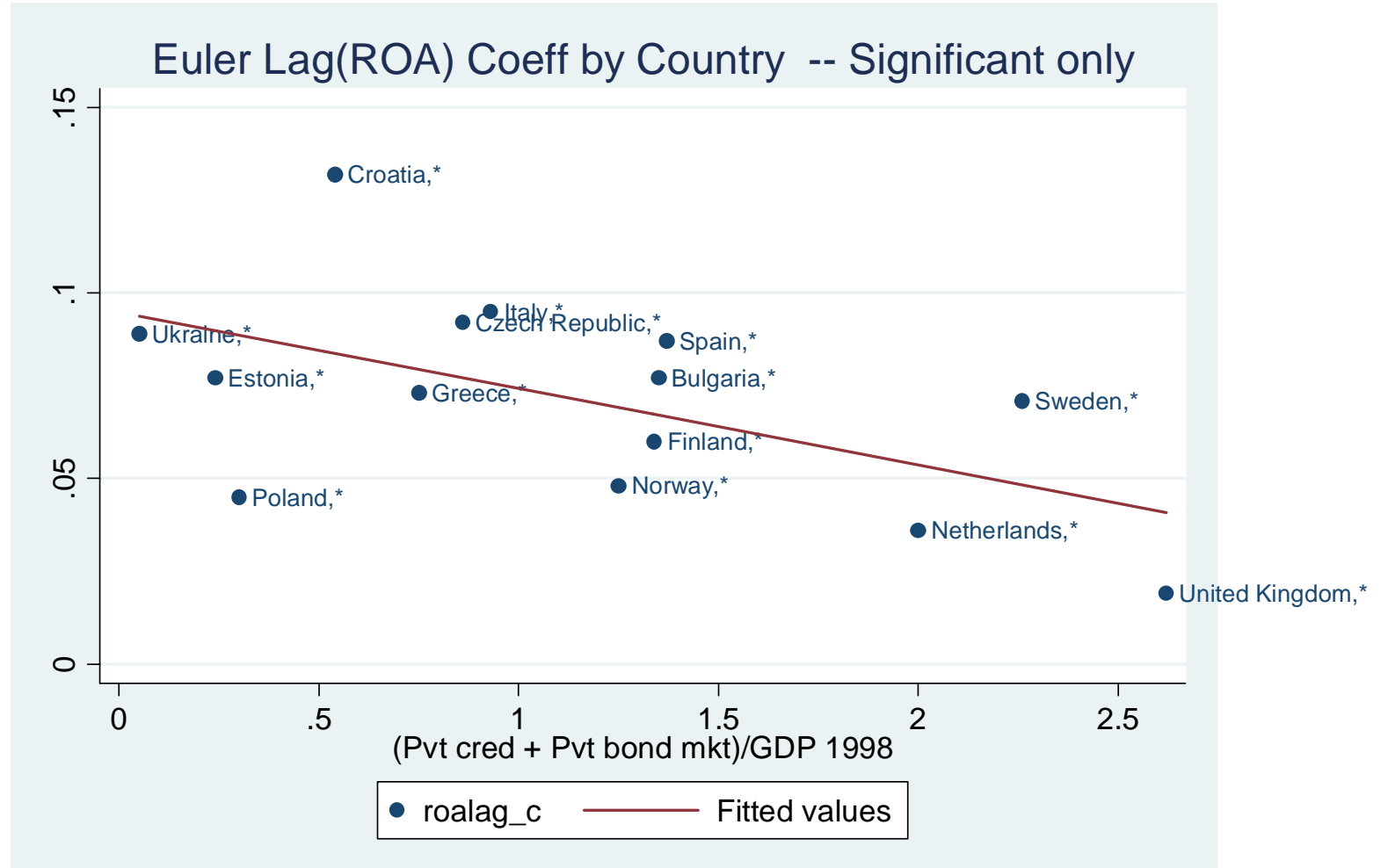




\section{Table A.2: Country wise results for the Econometric model}

Dependent variable in all regressions is gross investment (normalized by assets). Cash flow is defined as cash flow after taxes and interest over fixed assets. All regressions include the firm level variables and industry-year fixed effects used in the Econometric model specification in Table 1 (see text). Standard errors are clustered by industryyear. A plus sign $(+)$ denotes a significant coefficient at the $10 \%$ level, one star $\left(^{*}\right)$ denotes significance at the $5 \%$ level, two stars at the $1 \%$ level.

\begin{tabular}{lcc}
\hline \hline Country Name & $\begin{array}{c}\text { Lagged } \\
\text { Cash flow } \\
\text { Coefficient }\end{array}$ & $\begin{array}{c}\text { Lagged Cash } \\
\text { flow Standard } \\
\text { Error }\end{array}$ \\
\hline \hline Austria & -0.028 & {$[0.215]$} \\
Bosnia And Herzegovina & 0.147 & {$[0.140]$} \\
Belgium & $0.071^{* *}$ & {$[0.012]$} \\
Bulgaria & $0.058^{+}$ & {$[0.030]$} \\
Switzerland & 0.083 & {$[0.122]$} \\
Serbia And Montenegro & $0.309^{* *}$ & {$[0.078]$} \\
Czech Republic & $0.227^{* *}$ & {$[0.037]$} \\
Germany & $0.079^{+}$ & {$[0.041]$} \\
Denmark & $0.061^{+}$ & {$[0.031]$} \\
Estonia & $0.133^{* *}$ & {$[0.021]$} \\
Spain & $0.098^{* *}$ & {$[0.009]$} \\
Finland & $0.053^{* *}$ & {$[0.017]$} \\
France & $0.055^{* *}$ & {$[0.005]$} \\
United Kingdom & $0.014^{*}$ & {$[0.006]$} \\
Greece & $0.062^{* *}$ & {$[0.010]$} \\
Croatia & $0.266^{* *}$ & {$[0.026]$} \\
Hungary & -0.781 & {$[0.627]$} \\
Italy & $0.199^{* *}$ & {$[0.010]$} \\
Luxembourg & $0.255^{* *}$ & {$[0.058]$} \\
Latvia & -0.197 & {$[0.225]$} \\
Netherlands & 0.032 & {$[0.035]$} \\
Norway & 0.017 & {$[0.014]$} \\
Poland & $0.082^{* *}$ & {$[0.023]$} \\
Portugal & 0.002 & {$[0.071]$} \\
Sweden & $0.102^{* *}$ & {$[0.013]$} \\
Ukraine & 0.063 & {$[0.043]$} \\
\hline \hline
\end{tabular}




\section{Figure A.2: Constraints versus financial development (Econometric model)}

This figure plots the coefficients on lagged ROA from the Econometric equation model versus PCBB, for countries where the coefficient is significant. PCBB is the sum of private credit and total private bond market capitalization divided by GDP.

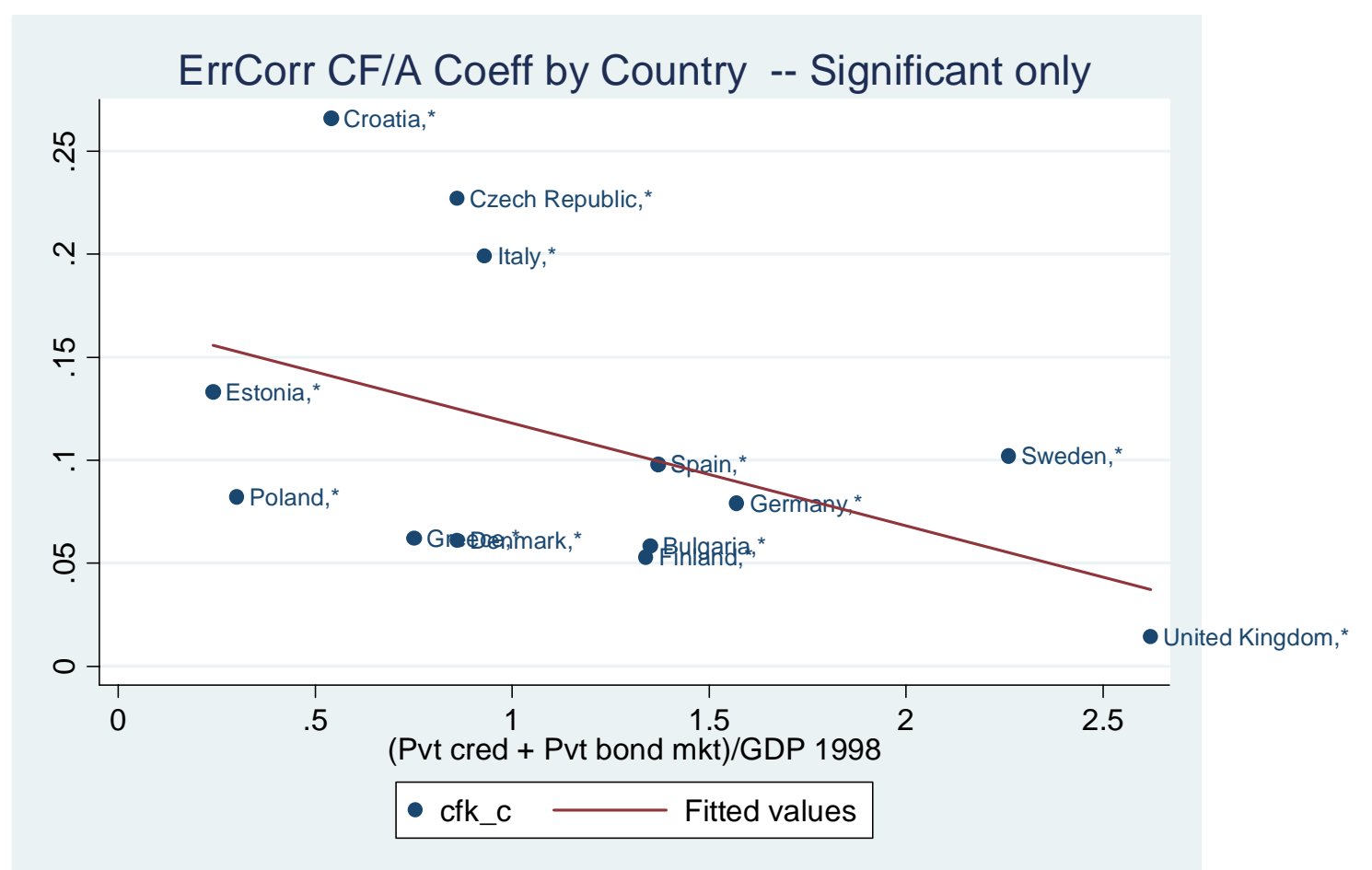




\section{Table A.3: Regression of country-wise coefficients on financial development}

Column (1) reports results from regression of the country-wise coefficients on Lagged ROA (reported in Table A.1) on PCBB. Column (2) reports results from regression of the country-wise coefficients on Cash flow (reported in Table A.1) on PCBB. PCBB is the sum of private credit and total private bond market capitalization divided by GDP. To account for the standard errors of the coefficients, each observation is weighted by the inverse of the estimated variance of the dependent variable.

(1)

(2)

Euler Equation Econometric

\begin{tabular}{lcc} 
& Model & Model \\
\hline \hline & & \\
PCBB & $-\mathbf{0 . 0 3 2 ^ { * * }}$ & $-\mathbf{0 . 0 5 0 * *}$ \\
& {$[0.006]$} & {$[0.0151]$} \\
Constant & $\mathbf{0 . 1 0 9 ^ { * * }}$ & $\mathbf{0 . 1 5 5 ^ { * * }}$ \\
& {$[0.011]$} & {$[0.027]$} \\
& & \\
R-squared & 0.629 & 0.380 \\
Observations & 20 & 20 \\
\hline \hline
\end{tabular}




\section{European Central Bank Working Paper Series}

For a complete list of Working Papers published by the ECB, please visit the ECB's website (http://www.ecb.int)

65 I "On the determinants of external imbalances and net international portfolio flows: a global perspective" by R. A. De Santis and M. Lührmann, July 2006.

652 "Consumer price adjustment under the microscope: Germany in a period of low inflation" by J. Hoffmann and J.-R. Kurz-Kim, July 2006.

653 "Acquisition versus greenfield: the impact of the mode of foreign bank entry on information and bank lending rates” by S. Claeys and C. Hainz, July 2006.

654 "The German block of the ESCB multi-country model" by I. Vetlov and T. Warmedinger, July 2006.

655 "Fiscal and monetary policy in the enlarged European Union" by S. Pogorelec, July 2006.

656 "Public debt and long-term interest rates: the case of Germany, Italy and the USA" by P. Paesani, R. Strauch and M. Kremer, July 2006.

657 "The impact of ECB monetary policy decisions and communication on the yield curve" by C. Brand, D. Buncic and J. Turunen, July 2006.

658 "The response of firms" investment and financing to adverse cash flow shocks: the role of bank relationships" by C. Fuss and P. Vermeulen, July 2006.

659 "Monetary policy rules in the pre-EMU era: Is there a common rule?" by M. Eleftheriou, D. Gerdesmeier and B. Roffia, July 2006.

660 "The Italian block of the ESCB multi-country model" by E. Angelini, A. D'Agostino and P. McAdam, July 2006.

66I "Fiscal policy in a monetary economy with capital and finite lifetime" by B. Annicchiarico, N. Giammarioli and A. Piergallini, July 2006.

662 "Cross-border bank contagion in Europe" by R. Gropp, M. Lo Duca and J. Vesala, July 2006.

663 "Monetary conservatism and fiscal policy" by K. Adam and R. M. Billi, July 2006.

664 "Fiscal convergence before entering the EMU" by L. Onorante, July 2006.

665 "The euro as invoicing currency in international trade" by A. Kamps, August 2006.

666 "Quantifying the impact of structural reforms" by E. Ernst, G. Gong, W. Semmler and L. Bukeviciute, August 2006.

667 "The behaviour of the real exchange rate: evidence from regression quantiles" by K. Nikolaou, August 2006.

668 "Declining valuations and equilibrium bidding in central bank refinancing operations" by C. Ewerhart, N. Cassola and N. Valla, August 2006. 
669 "Regular adjustment: theory and evidence" by J. D. Konieczny and F. Rumler, August 2006.

670 "The importance of being mature: the effect of demographic maturation on global per-capita GDP” by R. Gómez and P. Hernández de Cos, August 2006.

67 I "Business cycle synchronisation in East Asia” by F. Moneta and R. Rüffer, August 2006.

672 "Understanding inflation persistence: a comparison of different models" by H. Dixon and E. Kara, September 2006.

673 “Optimal monetary policy in the generalized Taylor economy” by E. Kara, September 2006.

674 “A quasi maximum likelihood approach for large approximate dynamic factor models" by C. Doz, D. Giannone and L. Reichlin, September 2006.

675 “Expansionary fiscal consolidations in Europe: new evidence” by A. Afonso, September 2006.

676 "The distribution of contract durations across firms: a unified framework for understanding and comparing dynamic wage and price setting models” by H. Dixon, September 2006.

677 “What drives EU banks' stock returns? Bank-level evidence using the dynamic dividend-discount model” by O. Castrén, T. Fitzpatrick and M. Sydow, September 2006.

678 "The geography of international portfolio flows, international CAPM and the role of monetary policy frameworks” by R. A. De Santis, September 2006.

679 "Monetary policy in the media” by H. Berger, M. Ehrmann and M. Fratzscher, September 2006.

680 “Comparing alternative predictors based on large-panel factor models” by A. D'Agostino and D. Giannone, October 2006.

68I "Regional inflation dynamics within and across euro area countries and a comparison with the US" by G. W. Beck, K. Hubrich and M. Marcellino, October 2006.

682 “Is reversion to PPP in euro exchange rates non-linear?” by B. Schnatz, October 2006.

683 "Financial integration of new EU Member States" by L. Cappiello, B. Gérard, A. Kadareja and S. Manganelli, October 2006.

684 "Inflation dynamics and regime shifts" by J. Lendvai, October 2006.

685 "Home bias in global bond and equity markets: the role of real exchange rate volatility" by M. Fidora, M. Fratzscher and C. Thimann, October 2006

686 "Stale information, shocks and volatility" by R. Gropp and A. Kadareja, October 2006.

687 "Credit growth in Central and Eastern Europe: new (over)shooting stars?" by B. Égert, P. Backé and T. Zumer, October 2006.

688 "Determinants of workers' remittances: evidence from the European Neighbouring Region" by I. Schiopu and N. Siegfried, October 2006.

689 "The effect of financial development on the investment-cash flow relationship: cross-country evidence from Europe" by B. Becker and J. Sivadasan, October 2006. 
